\title{
Letter to the Editor in Response to "Effect of Polymorphisms in CYP2C9 and CYP2C19 on the Disposition, Safety and Metabolism of Progesterone Administrated Orally or Vaginally"
}

\author{
Aaron Lazorwitz - Christina L. Aquilante - Jeanelle Sheeder • \\ Stephanie Teal
}

Received: October 8, 2019 / Published online: December 24, 2019

(C) The Author(s) 2019

Keywords: Etonogestrel; Pharmacogenomics; Progesterone; Women's health

First available online on September 3, 2019 in Advances in Therapy, Zubiaur et al. [1] suggested that the CYP2C19 phenotype may help explain some of the variability in serum progesterone concentrations when taken orally or vaginally and stated that there are "no other pharmacogenetic studies of progesterone" with which to compare their results. In fact, our published pharmacogenomics study of etonogestrel metabolism is an important comparator [2]. Etonogestrel, a progestin found in some forms of contraception including the continuous-release subdermal implant, is metabolized in very similar processes to progesterone [3]. Clinical data also support that the etonogestrel

Enhanced Digital Features To view enhanced digital features for this article go to https://doi.org/10.6084/ m9.figshare.11347016.

\section{A. Lazorwitz $(\bowtie) \cdot J$. Sheeder $\cdot$ S. Teal}

Division of Family Planning, Department of Obstetrics and Gynecology, University of Colorado

Anschutz Medical Campus, Aurora, CO, USA

e-mail: Aaron.lazorwitz@ucdenver.edu

C. L. Aquilante

Department of Pharmaceutical Sciences, Skaggs

School of Pharmacy and Pharmaceutical Sciences,

University of Colorado Anschutz Medical Campus,

Aurora, CO, USA contraceptive implant and other progestins (e.g., dienogest) have similar pharmacological properties as progesterone, further supporting common metabolic and pharmacodynamic pathways between these steroid hormones $[4,5]$. Like Zubiaur and colleagues, we utilized a candidate gene approach for our investigation, including genetic variants in CYP2C19, $C Y P 2 C 9$, and three other metabolizing enzyme genes (CYP3A4, CYP3A5, CYP3A7). However, unlike Zubiaur et al. [1], we did not find that variants in CYP2C19 were associated with differences in serum etonogestrel concentrations among our 350 contraceptive implant users [2]. Alternatively, we found that a variant in CYP3A7 (the ${ }^{*} 1 C$ variant) was significantly associated with $23 \%$ lower etonogestrel concentrations than the respective wild-type genotype [2]. We also found that body mass index was significantly associated with serum etonogestrel concentrations and should be accounted for in pharmacokinetic investigations with similar steroid hormones [2].

We agree with Zubiaur and colleagues that genome wide association studies are needed to further explore the pharmacogenomics of steroid hormones, particularly in light of the findings by Zhang et al. [6] regarding the limited role that CYP3A4 appears to have in the metabolism of steroid hormones. However, given the disparate findings regarding CYP2C19 variants between our studies, additional research is 
warranted to determine how much this specific CYP isoenzyme and variants within its gene truly influence progesterone and progestin metabolism.

\section{ACKNOWLEDGEMENTS}

Funding. Our work cited in this article was primarily supported by the Society of Family Planning Research Fund [Grant Number SFPRF17-3] and was also supported by NIH/ NCATS Colorado CTSA Grant Number UL1 TR001082. No funding or sponsorship was received for publication of this article.

Authorship. All named authors meet the International Committee of Medical Journal Editors (ICMJE) criteria for authorship for this article, take responsibility for the integrity of the work as a whole, and have given their approval for this version to be published.

Disclosures. Stephanie Teal has served on scientific advisory boards of Allergan and Bayer Healthcare, and serves on a data monitoring board for a study funded by Merck and Co. Stephanie Teal and Aaron Lazorwitz receive research funding from Merck and Co. for an investigator initiated study on drug-drug interactions with the etonogestrel contraceptive implant. The University of Colorado Department of Obstetrics and Gynecology has received research funding from Bayer, Agile Therapeutics, Sebela, Merck and Co, and Medicines 360. Jeanelle Sheeder and Christina Aquilante have nothing to disclose.

Compliance with Ethics Guidelines. This article is based on previously conducted studies and does not contain any studies with human participants or animals performed by any of the authors.

Peer Review. Please note, contrary to the journal's standard single-blind peer review process, as a commentary this article underwent review by a member of the journal's Editorial Board.
Open Access. This article is licensed under a Creative Commons Attribution-NonCommercial 4.0 International License, which permits any non-commercial use, sharing, adaptation, distribution and reproduction in any medium or format, as long as you give appropriate credit to the original author(s) and the source, provide a link to the Creative Commons licence, and indicate if changes were made. The images or other third party material in this article are included in the article's Creative Commons licence, unless indicated otherwise in a credit line to the material. If material is not included in the article's Creative Commons licence and your intended use is not permitted by statutory regulation or exceeds the permitted use, you will need to obtain permission directly from the copyright holder. To view a copy of this licence, visit http://creativecommons.org/licenses/by$\mathrm{nc} / 4.0 /$.

\section{REFERENCES}

1. Zubiaur P, Ochoa D, Galvez MA, et al. Effect of polymorphisms in CYP2C9 and CYP2C19 on the disposition, safety and metabolism of progesterone administrated orally or vaginally. Adv Ther. 2019;36: 2744-55.

2. Lazorwitz A, Aquilante CL, Oreschak K, Sheeder J, Guiahi $\mathrm{M}$, Teal S. Influence of genetic variants on steady-state etonogestrel concentrations among contraceptive implant users. Obstet Gynecol. 2019;133(4):783-94.

3. Hatcher RA, Trussell J, Stewart F, et al. Contraceptive technology. New York: Ardent Media; 2011.

4. Carvalho N, Margatho D, Cursino K, Benetti-Pinto CL, Bahamondes L. Control of endometriosis-associated pain with etonogestrel-releasing contraceptive implant and $52 \mathrm{mg}$ levonorgestrel-releasing intrauterine system: randomized clinical trial. Fertil Steril. 2018;110(6):1129-36.

5. Lagana AS, Vitale SG, Granese R, et al. Clinical dynamics of dienogest for the treatment of endometriosis: from bench to bedside. Expert Opin Drug Metab Toxicol. 2017;13(6):593-6.

6. Zhang N, Shon J, Kim MJ, et al. Role of CYP3A in oral contraceptives clearance. Clin Transl Sci. 2018;11(3): 251-60. 